NikLes, D. G. and A. R. GRIFFIN (1992): Breeding hybrids of forest trees: Definitions, theory, some practical examples, and guidelines on strategy with tropical Acacias, pp. 101-109. In: Proceedings of a workshop on: Breeding technologies for tropical Acacias, edited by L. T. CArron and K. M. Aken, ACIAR, Tawau, Sabah, Malaysia.

Ochieng, J., M. Shepherd, P. R. Baverstock, D. G. NikLES, D. J. LEE and R. J. HenRY (2008): Genetic variation within two sympatric spotted gum eucalypts exceeds between taxa variation. Silvae Genetica 57: 249-256.

Potts, B. M. and H. Dungey (2004): Interspecific hybridisation of Eucalyptus: key issues for tree breeders and geneticists. New Forests 27: 115-138.

Shelbourne, C. J. A. (2000): Some insights on hybrids in forest tree improvement, pp. 53-62. In: Hybrid breeding and genetics of forest trees, Proceedings of QFRI/CRCSPF Symposium, editors H. S. DungeY, M. J. DieTERS and D. G. NikLES, Department of Primary Industries, Brisbane, Australia.

Shepherd, M., P. Pomroy, M. Dieters and D. J. Lee (2007): Genetic control of propagation traits in a single Corymbia torelliana $\times$ C. variegata family. Canadian Journal of Forest Research 37: 2563-2574.

Shepherd, M., S. Kasem, G. Ablett, J. Ochieng and A. CRAWFORD (2008): Genetic structuring in the spotted gum complex (genus Corymbia, section Politaria). Australian Systematic Botany 21: 15-25.
Trueman, S. J. and D. M. RichaRdson (2008): Relationships between Indole-3-Butyric Acid, Photoinhibition and Adventitious Rooting of Corymbia torelliana, C. citriodora and $\mathrm{F}_{1}$ Hybrid Cuttings. Tree and Forestry Science and Biotechnology 2: 26-33.

VenKatesh, C. S. and V. K. Sharma (1977): Hybrid vigour in controlled interspecific crosses of Eucalyptus tereticornis $\times$ E. camaldulensis. Silvae Genetica 26: 121-124.

VERRYN, S. D. (2000): Eucalyptus hybrid breeding in South Africa, pp. 191-199. In: Hybrid breeding and genetics of forest trees, Proceedings of QFRI/CRCSPF Symposium, editors H. S. Dungey, M. J. Dieters and D. G. NiKLES, Department of Primary Industries, Brisbane, Australia.

Vigneron, P., J. M. Bouvet, R. Gouma, A. SAya, J. M. Gion and D. VERHAEGEN (2000): Eucalypt hybrids breeding in Congo, pp. 14-26. In: Hybrid breeding and genetics of forest trees, Proceedings of QFRI/CRCSPF Symposium, editors H. S. Dungey, M. J. Dieters and D. G. NikLES, Department of Primary Industries, Brisbane, Australia.

VolKer, P. W. (1995): Evaluation of Eucalyptus nitens x globulus for commercial forestry. Pages 222-225 in B. M. Potts, N. M. G. Borralho, J. B. Reid, R. N. Cromer, W. N. Tibbits and C. A. Raymond, editors. Eucalypt plantations: Improving fibre yield and quality. CRC-IUFRO, Hobart, Australia

White, T. L., W. T. Adams and D. B. Neile (2007.): Forest Genetics. Cabi Publishing Oxfordshire UK.

\title{
Performance and Genetic Parameters of Somatic and Zygotic Progenies of Coastal Douglas-fir at 71/2-Years across Washington and Oregon, USA
}

\author{
By C. A. Dean ${ }^{\left.1),{ }^{*}\right)}$, D. E. Welty ${ }^{1)}$ and G. E. HerolD ${ }^{2)}$
}

(Received 23 $3^{\text {rd }}$ May 2008)

\begin{abstract}
Five genetic tests involving 37 somatic clones of coastal Douglas-fir (Pseudotsuga menziesii var. menziesii) were planted March 2000 in Weyerhaeuser plantations across western Washington and Oregon States, USA. Four of the tests are in Longview, Twin Harbors and Vail regions of Washington, and one test is in Springfield, Oregon. Each test is based on single-tree plots with 12 randomized complete-blocks. The 37 coastal Douglas-fir clones were propagated by somatic

1) Present address: Weyerhaeuser Company, PO Box 9777, Federal Way, WA 98063-9777, USA.

$\left.{ }^{2}\right)$ Weyerhaeuser Company, George Staebler Research Center, PO Box 420, Centralia, WA 98531-0420, USA.

*) Corresponding author: Christine A. DeAn. E-Mail: Christine. Dean@Weyerhaeuser.com
\end{abstract}

embryogenesis from four full-sib families. Zygotic seedlings from two of these full-sib families were planted across all five tests to allow comparison between somatic and zygotic trees of the same pedigree. Results are reported for survival, stem height, diameter at breast-height $(\mathrm{DBH})$, volume and stem sinuosity at $71 / 2$ years.

On average the total population of 37 somatic clones had less stem sinuosity, but grew more slowly than zygotic trees across the five tests studied. However, the best $20 \%$ of somatic clones for growth produced $25 \%$ greater stem volume at $7 \frac{1}{2}$-years than the zygotic fullsib families. Height had a clonal heritability of $0.61 \pm 0.09, \mathrm{DBH} 0.64 \pm 0.06$, volume $0.58 \pm 0.08$ and stem sinuosity $0.26 \pm 0.06$. The clonal genetic correlation between height and $\mathrm{DBH}$ at $7 \frac{1}{2}$-years was $0.98 \pm 0.01$, while stem sinuosity was adversely genetically correlated with growth. Clonal performance for 
growth and stem sinuosity was stable across tests with overall between-test correlations of 0.96 to 0.98 . This clonal stability resulted in little variance due to clone $\mathrm{x}$ test interactions.

Key words: Coastal Douglas-fir, somatic and zygotic trees, growth and form, clonal heritabilities, clonal stability.

\section{Introduction}

Coastal Douglas-fir (Pseudotsuga menziesii var. menziesii) is among the most important commercial forest tree species in North America and, since the early $1960 \mathrm{~s}$, has been the focus of quite intensive genetic improvement. Weyerhaeuser Company manages one of the most advanced improvement programs of coastal Douglas-fir that is well into its third generation of breeding and selection (STONECYPHER et al., 1996; DEAN, 2007). A core part of Weyerhaeuser's advanced-generation improvement strategy is the use of somatic embryogenesis (SE) and manufactured seed technologies to bring more concentrated investment on elite genotypes in nucleus populations (DEAN, 2007; DEAN, 2008).

$\mathrm{SE}$ is an in vitro tissue culture technique that involves repeating the normal polyembryony process in zygotic seed embryo development to produce genetically identical embryos that can be grown as clonal trees for testing and plantation establishment (DUNSTAN, 1988; CHELIAK and Rogers, 1990; TAUTORUs et al., 1991; RoBERTs et al., 1995; GrossnickLe et al., 1996; SutTon, 2002). NAGMANI et al. (1991) and GUPTA et al. (1994) reported various aspects of SE technologies applied specifically to Douglas-fir. However, the published literature for somatic Douglas-fir is quite scarce in terms of: (i) Comparisons of field performance of somatic versus zygotic trees, and (ii) estimates of clonal genetic parameters. A thorough analysis of genetic improvement strategies with SE and the integration of $\mathrm{SE}$ technologies into conventional genetic improvement programs require reliable estimates of genetic parameters including clonal heritabilities, clonal genetic variances and clonal correlations.

BENOwICZ et al. (2002) present physiological attributes and frost hardiness of somatic and zygotic seedlings of coastal Douglas-fir measured over two growing seasons in a field test in British Columbia; but did not report growth traits. DEAN (2008) estimated growth performance and genetic parameters of somatic clones of coastal Douglas-fir at 51/2-years across a range of sites in Washington and Oregon; but did not compare somatic and zygotic trees.

In 2000 Weyerhaeuser established five genetic field tests involving 37 somatic clones of coastal Douglas-fir across Washington and Oregon, Pacific Northwest USA. The principal objectives of these genetic field tests were to: (i) evaluate growth and stem quality of somatic and zygotic trees in plantations; (ii) estimate clonal genetic parameters such as variances, heritabilities and correlations; and (iii) determine the stability of clonal performance across tests. This paper presents results of these tests for growth and stem quality of somatic and zygotic trees at $7 \frac{1}{2}$-years.

\section{Experimental Details}

\section{Sites, Establishment and Silviculture}

The five genetic tests were planted March 2000 in Weyerhaeuser Company plantations across western Washington and Oregon States using the following genetic material of coastal Douglas-fir: (i) somatic seedlings of 37 clones propagated from four full-sib families, and (ii) full-sib zygotic seedlings from two of the four families. Test LV1 is in the Longview region of Washington; TH2 and TH3 in Twin Harbors, Washington; VA4 in Vail, Washington; and SP5 in Springfield, Oregon (site details are summarized in Table 1). All five tests were planted by hand using containerized seedlings at 3,020 trees per hectare $(1.82 \mathrm{~m} \times 1.82 \mathrm{~m})$.

\section{Genetic Material}

(1) Somatic Clones: The 37 coastal Douglas-fir clones were propagated by SE from four full-sib families produced by crossings among six parents: 14 clones were propagated from family $\mathrm{AxB}$ (female A x male B), 6 clones from $\mathrm{AxC}, 14$ from $\mathrm{DxE}$ and three clones from FxB. The parents were all first-generation plus trees selected by Weyerhaeuser in the mid-1960s from 60-80year-old natural stands of coastal Douglas-fir growing below $600 \mathrm{~m}$ in either Twin Harbors (in the case of parents A, B and C) or Longview region (Parents D, E and F). The Twin Harbors families $\mathrm{AxB}$ and $\mathrm{AxC}$ both demonstrated superior stem volume growth in zygotic field tests that were part of Weyerhaeuser's first-generation breeding of coastal Douglas-fir. The Longview fami-

Table 1. - Site parameters for genetic tests LV1 (Longview, Washington); TH2 and TH3 (Twin Harbors, Washington); VA4 (Vail, Washington); and SP5 (Springfield, Oregon).

\begin{tabular}{|c|c|c|c|c|c|}
\hline & LV1 & $\mathrm{TH} 2$ & TH3 & VA4 & SP5 \\
\hline Plantation & Headquarters & Fall River & $\begin{array}{l}\text { Bunker } \\
\text { Creek }\end{array}$ & $\begin{array}{c}\text { Thompson } \\
\text { Creek }\end{array}$ & Wendling \\
\hline Region & Longview & $\begin{array}{l}\text { Twin } \\
\text { Ilarbors }\end{array}$ & $\begin{array}{l}\text { Twin } \\
\text { I larbors }\end{array}$ & Vail & Springfield \\
\hline Elevation (m) & 320 & 330 & 180 & 230 & 440 \\
\hline Slope & $5 \%$ & $5 \%$ & $5 \%$ & $10 \%$ & $20-40 \%$ \\
\hline Soil association & Morgan & Boistfort & Melbourne & Melbourne & Peavine \\
\hline Soil texture & Clay loam & Clay loam & Silty clay & Silty clay & Clay \\
\hline Site index & 130 & 130 & 130 & 130 & 120 \\
\hline
\end{tabular}


ly DxE had superior stem sinuosity and branch habit in field tests and was part of a "stem quality" nucleus breeding population.

(2) Zygotic Families: The full-sib zygotic seedlings represented two of the four full-sib families from which 28 of the 37 somatic clones had been developed; namely family $\mathrm{AxB}$ selected on growth and $\mathrm{DxE}$ selected on stem quality. This full-sib zygotic material is used in this study to compare the performance of somatic and zygotic trees of equivalent pedigree.

\section{Somatic Embryogenesis Technology}

The somatic seedlings were produced using SE procedures for Douglas-fir developed from research at the beginning of the 1990s (GUPTA et al., 1994). The protocol started with excising immature zygotic embryos from variable numbers of seeds of each of the four full-sib families. Embryonic suspensor masses (ESM) were then initiated in vitro from the individual excised embryos using a semi-solid medium containing mineral nutrients, sucrose and vitamins. The next step involved multiplication of the ESM cultures by weekly subculture in fresh liquid medium. An in vitro development step followed in which mature somatic embryos were produced on pads soaked in high osmolality liquid development medium containing abscisic acid, gibberellic acid and activated charcoal.

Healthy embryos of normal size and morphology (as compared with zygotic embryos) were selected by hand from the development medium with the aid of a stereo microscope. The selected embryos were transferred onto semi-solid medium and incubated for the first 5-7 days in the dark followed by transfer to light for eight weeks to produce germinants with epicotyls. The germinants were then transferred to ex vitro nursery conditions. This transfer involved the individual selection of good quality (based on size and morphology) somatic germinants with epicotyls. These germinants were transplanted into a mixture of peat, vermiculite and perlite in $164 \mathrm{~cm}^{3}$ "supercell" containers. All somatic and zygotic seedlings were cultured in the same way in the same greenhouse for one spring/summer growing season, followed by fall hardening and winter cold storage prior to field planting in March 2000. At the time of planting the somatic and zygotic seedlings had similar size and morphology.

\section{Field Design}

Each of the five genetic tests are based on single-tree plots of the 37 somatic clones randomized across 12 complete replicates; giving 12 trees planted per clone per test. Each of the two full-sib families was planted in separate 40 -tree plots with six replicates per site. These replicates were usually planted adjacent to a pair of single-tree-plot replicates.

\section{Measurements}

In fall 2007 (71/2-years after planting) all surviving trees in all tests were measured for height using poles; stem diameter over-bark at breast-height (DBH at 137 $\mathrm{cm})$ using diameter tape; and stem sinuosity using a score. Stem volume over-bark was calculated from diameter and height for each tree using the small-tree volume equation of BRUCE and DEMARS (1974). Stem sinuosity was assessed by estimating deflection of the stem from vertical using the following five scores: score $0=$ straight, score $0.25=$ approximately $0.64 \mathrm{~cm}$ deflection, score $0.5=1.27 \mathrm{~cm}$, score $1=2.54 \mathrm{~cm}$ (one inch), and score $2=5.08 \mathrm{~cm}$ or more. Survival was calculated as the percent of trees planted that survived to $7 \frac{1}{2}$-years.

\section{Statistical Methods}

(1) Statistical Package: All analyses were carried out using the ASREML (GILMOUR et al., 2006) statistical package. ASREML is based on "Restricted Maximum Likelihood" methodology (PATTERsON and THOMPSON, 1971; SEARLE et al., 1992). The program makes optimal use of all available information, has considerable flexibility in the range of models that can be fitted and its solutions for random effects are BLUP (Best Linear Unbiased Prediction).

(2) MODEL 1: Was fitted to $7 \frac{1}{2}$-year data for the 37 somatic clones and the two zygotic families pooled across the five genetic tests. This MODEL 1 was used to compare somatic clones with zygotic families and to predict clonal values for each trait - (1)

$$
\begin{aligned}
\text { TRAIT }_{\mathrm{ijklm}}= & \mu+\text { TEST }_{\mathrm{i}}+\text { PROP }_{\mathrm{j}}+\text { TEST.PROP }_{\mathrm{ij}}+\operatorname{REP}_{\mathrm{ijk}} \\
& + \text { FAMILY }_{\mathrm{jl}}+\text { CLONE }_{l \mathrm{~m}}+\operatorname{RESIDUAL}_{\mathrm{ijklm}}
\end{aligned}
$$

where TRAIT $_{\text {ijklm }}$ is the observation on the mth tree of the appropriate propagule type, family, replicate and test; $\mu$ is a fitted mean; TEST $T_{i}$ is the effect of the ith test site ( $i=1-5$ ), assumed to be a fixed effect; $\mathrm{PROP}_{\mathrm{j}}$ is the fixed effect of the $\mathrm{jth}$ propagule type $(\mathrm{j}=1-2)$; TEST.PROP ${ }_{\mathrm{ij}}$ is their interaction; $\operatorname{REP}_{\mathrm{ijk}}$ is a propagule-specific random effect of the kth replication nested within the ith test $\left(\mathrm{k}_{1}=1-12\right.$ for somatic clones and $\mathrm{k}_{2}=1-6$ for zygotic families); FAMILY ${ }_{j 1}$ is the random effect of the lth family within the jth propagule type $(1=1-4$ for clones and $1=1-2$ for zygotic families); CLONE $1 \mathrm{~lm}$ is the random effect of the mth somatic clone within the lth full-sib family, and RESIDUAL ${ }_{\mathrm{ijklm}}$ is a residual error. The FAMILY effect could be treated as fixed, however, in MoDEL 1 it is fitted as a random effect to generate variance components.

(3) MODEL 2: Data from the zygotic families were excluded from this and subsequent models - (2)

$$
\begin{aligned}
\text { TRAIT }_{\text {ijklm }}= & \mu+\text { TEST }_{\mathrm{i}}+\text { REP }_{\mathrm{ij}}+\text { FAMILY }_{\mathrm{k}}+ \\
& \text { CLONE }_{\mathrm{kl}}+\text { FAMILY.TEST }_{\mathrm{ik}}+ \\
& \text { CLONE.TEST }_{\mathrm{ikl}}+\text { RESIDUAL }_{\mathrm{ijklm}}
\end{aligned}
$$

where TRAIT $_{\mathrm{ijklm}}$ is the observation on the mth tree of the lth somatic clone from the kth full-sib family and growing in the jth replicate at the ith test; $\mu$ is a fitted mean; TEST $_{\mathrm{i}}$ is the fixed effect of the ith test site $(\mathrm{i}=1-5)$; $\mathrm{REP}_{\mathrm{ij}}$ is the random effect of the jth replication nested within the ith test $(\mathrm{j}=1-12)$ FAMILY $_{\mathrm{k}}$ is the random effect of the $\mathrm{kth}$ full-sib family ( $\mathrm{k}=1-4) ; \mathrm{CLONE}_{\mathrm{kl}}$ is the random effect associated with the lth somatic clone nested within the kth full-sib family $(1=1-14$ in families $\mathrm{AxB}$ and DxE, 6 in $\mathrm{AxC}$, and 3 in $\mathrm{FxB}$ ); FAMILY.TEST $\mathrm{ik}_{\text {is }}$ the interaction of family and genetic test; CLONE.TEST ${ }_{\mathrm{ikl}}$ is the 
interaction of clone and test; and $\operatorname{RESIDUAL}_{\mathrm{ijklm}}$ is a residual error among the mth trees within the lth clone. It is important to note that any propagation effects that may be associated with particular clones but not of genetic origin ("c-effects") are completely confounded with CLONE $_{\mathrm{kl}}$. Commonly c-effects in conifers are attributed to environmental factors associated with the rooting of the clone (IsIK et al., 2003; BALTUNIS et al., 2005). There appear to be no published studies examining c-effects in somatic Douglas-fir trees.

Model 2 was used to estimate variance components for the effects of FAMILY (denoted $\sigma_{\mathrm{F}}^{2}$ ), CLONE $\left(\sigma_{\mathrm{C}}^{2}\right)$, FAMILY.TEST interaction $\left(\sigma_{\mathrm{FT}}^{2}\right)$, CLONE.TEST interaction $\left(\sigma_{\mathrm{CT}}^{2}\right)$ and the RESIDUAL within-clone error $\left(\sigma_{\mathrm{e}}^{2}\right)$. Overall phenotypic variance $\left(\sigma_{\mathrm{P}}^{2}\right)$ was calculated as $-(3)$

$$
\sigma_{\mathrm{P}}^{2}=\sigma_{\mathrm{F}}^{2}+\sigma_{\mathrm{C}}^{2}+\sigma_{\mathrm{FT}}^{2}+\sigma_{\mathrm{CT}}^{2}+\sigma_{\mathrm{e}}^{2}
$$

Broad-sense clonal heritabilities $\left(\mathrm{H}^{2}{ }_{\mathrm{C}}\right)$ were defined as the ratio of between-clone (within-family) variance to phenotypic variance - (4)

$$
\mathrm{H}^{2}{ }_{\mathrm{C}}=\sigma_{\mathrm{C}}^{2} / \sigma_{\mathrm{P}}^{2}
$$

$\mathrm{H}^{2}{ }_{\mathrm{C}}$ is actually a repeatability parameter that gives an indication of the degree to which a somatic clone's superiority is repeatable, relative to other clones from the same family. The terms "clonal heritability" and "clonal repeatability" are both commonly used to describe $\mathrm{H}_{\mathrm{C}}^{2}$; in this study "clonal heritability" is used. Clonal variance $\left(\sigma_{C}^{2}\right)$ and heritability $\left(\mathrm{H}^{2}{ }_{\mathrm{C}}\right)$ were also estimated with effects due to families (i.e. FAMILY $\mathrm{k}_{\mathrm{k}}$ and FAMILY.TEST ${ }_{\mathrm{ik}}$ ) omitted from the model. In this case $\sigma_{\mathrm{C}}^{2}$ is variance among clones ignoring the effects of families, and $\mathrm{H}_{\mathrm{C}}^{2}$ the repeatability of a clone's relative performance ignoring families.

(4) ModeL 3: This model is a variant of Model 2 and was used to simultaneously estimate parameters specific to each individual test. In MoDEL 3 the FAMILY.TEST ${ }_{j k}$ interaction was omitted and the CLONE $\left(\sigma_{\mathrm{C}}^{2}\right)$ and Clone.Test $\left(\sigma_{\mathrm{CT}}^{2}\right)$ variances were partitioned into separate but correlated CLONE $\left(\sigma_{C}^{2}\right)$ components for each test. Separate residual variances were then fitted to each test to allow site-specific estimates of clonal heritability.
(5) MODEL 4: Is another variant of Model 2 and was used to estimate between-trait clonal correlations by adding an extra dimension to each term to accommodate bivariate structures, and also excluding the interaction terms. Two variances and a covariance were fitted for the replicate (within-test), clone (within-family) and error terms. Thus MoDEL 4 accommodates the two trait vector/matrix of effects while MoDEL 2 is univariate.

\section{Results and Discussion}

\section{General}

Total numbers of somatic and zygotic trees planted, their average survival and growth to $7 \frac{1}{2}$-years of age across the five genetic tests LV1, TH2, TH3, VA4 and SP5 are given in Table 2. Survival varied between tests and was marginally lower in somatic trees (88-92\%) than zygotics (90-95\%). The Vail test VA4 grew slightly more slowly with mean height $5.2 \mathrm{~m}$ averaged across all somatic trees compared with 5.4-5.8 m for somatics across the other tests (Table 2).

\section{Performance of Somatic and Zygotic Trees}

(1) Growth: On average the somatic trees grew more slowly than the zygotics of coastal Douglas-fir involved in this study. For example, the 28 somatic clones derived from families $\mathrm{AxB}$ and $\mathrm{DxE}$ reached mean volume $10.2 \mathrm{dm}^{3}$ at $71 / 2$-years across the five genetic tests; which is only about two-thirds the mean volume $15.1 \mathrm{dm}^{3}$ of all zygotic trees from the same families (Table 3). It is evident from Table 3 that average growth of all 37 somatic clones from four families was essentially the same as the average of 28 clones from two families. BENOwICZ et al. (2002) seem to provide the only previously published comparison of somatic and zygotic trees of coastal Douglas-fir in the field. These authors measured physiological attributes as well as frost hardiness of 192 each of somatic and zygotic seedlings over two growing seasons in a field test on Vancouver Island, British Columbia. The somatic and zygotic seedlings were comparable in terms of frost hardiness including spring bud break; attributes that can be extremely important for survival and production of Douglas-fir plantations. BENOWICZ et

Table 2. - Numbers of somatic and full-sib zygotic trees planted, their average survival and stem height at $7 \frac{1}{2}$-years across genetic tests LV1, TH2, TH3, VA4 and SP5.

\begin{tabular}{lccccc}
\hline & LV1 & TH2 & TH3 & VA4 & SP5 \\
\hline \hline & & & & & \\
Somatic Clones: & 37 & 37 & 37 & 37 & 32 \\
Clones planted (no) & 444 & 444 & 444 & 444 & 384 \\
Trees planted (no) & 399 & 403 & 389 & 397 & 355 \\
Trees measured (no) & $90 \%$ & $91 \%$ & $88 \%$ & $89 \%$ & $92 \%$ \\
Survival (\%) & 5.4 & 5.7 & 5.5 & 5.2 & 5.8 \\
Tree height (m) & & & & & \\
& 2 & 2 & 2 & 2 & 2 \\
Zygotic Families: & 480 & 480 & 480 & 480 & 480 \\
Families planted (no) & 449 & 448 & 441 & 434 & 455 \\
Trecs planted (no) & $94 \%$ & $93 \%$ & $92 \%$ & $90 \%$ & $95 \%$ \\
Trees measured (no) & 6.5 & 6.8 & 6.5 & 6.1 & 7.0 \\
Survival (\%) & & & & & \\
Tree height (m) & & & & & \\
\hline
\end{tabular}


Table 3. - ASRemL estimates with fitted Model 1 of overall means ( \pm standard errors) for stem height, diameter at breast-height ( $\mathrm{DBH})$, volume and stem sinuosity at $7 \frac{1}{2}$-years across tests LV1, TH2, TH3, VA4 and SP5 of the following genetic groups of coastal Douglas-fir: (1) the top eight (approximately 20\%) of the 37 clones for stem volume; (2) 28 somatic clones from Twin Harbors family AxB and Longview family DxE; (3) all 37 somatic clones from four full-sib families; and (4) the zygotic full-sib families $\mathrm{AxB}$ and $\mathrm{DxE}$.

\begin{tabular}{lcccc}
\hline Genetic group & $\begin{array}{c}\text { Height } \\
(\mathrm{m})\end{array}$ & $\begin{array}{c}\text { DBH } \\
(\mathrm{mm})\end{array}$ & $\begin{array}{c}\text { Volume } \\
\left(\mathrm{dm}^{3}\right)\end{array}$ & $\begin{array}{c}\text { Sinuosity } \\
(\mathrm{score})\end{array}$ \\
\hline & & & & \\
Top 8 of 37 clones for growth & $7.0 \pm 0.1$ & $84.5 \pm 1.3$ & $18.9 \pm 0.8$ & $0.63 \pm 0.25$ \\
28 clones from AxB \& DxE & $5.5 \pm 0.5$ & $61.5 \pm 3.8$ & $10.2 \pm 2.1$ & $0.36 \pm 0.13$ \\
All 37 clones (4 families) & $5.4 \pm 0.3$ & $61.2 \pm 2.9$ & $10.1 \pm 1.2$ & $0.34 \pm 0.07$ \\
Zygotic families AxB \& DxE & $6.6 \pm 0.6$ & $76.5 \pm 4.0$ & $15.1 \pm 2.7$ & $0.47 \pm 0.12$ \\
\hline
\end{tabular}

al. (2002) did not report direct estimates of growth of the different seedling types.

In an extensive study of 313 somatic clones from 11 full-sib families of interior spruce (Picea glauca), O'NEILL et al. (2005) reported slower growth of somatic trees compared with zygotics of the same ancestry at seven years after planting across two field sites in British Columbia. In a study of nursery plants of interior spruce hybrids GrossniCKLE et al. (1994) and GrossNICKLE and MAJOR (1994) found that somatic seedlings were shorter than zygotics in the first growing season.

It is interesting to note that clonal means for growth in the current study had a wide distribution. Figure 1 shows the frequency distribution of the 37 somatic clones for mean stem volume at $7 \frac{1}{2}$-years across tests. It is evident that 24 (or $65 \%$ ) of the 37 clones had quite low mean volumes of less than $12 \mathrm{dm}^{3}$ (Figure 1), while eight (or $20 \%$ ) of the clones had mean volumes greater than $15 \mathrm{dm}^{3}$ (approximately equal or better than the mean of the zygotic trees). Indeed these top eight somatic clones for volume growth had an overall mean volume of $18.9 \mathrm{dm}^{3}$; or $25 \%$ greater than the mean volume of

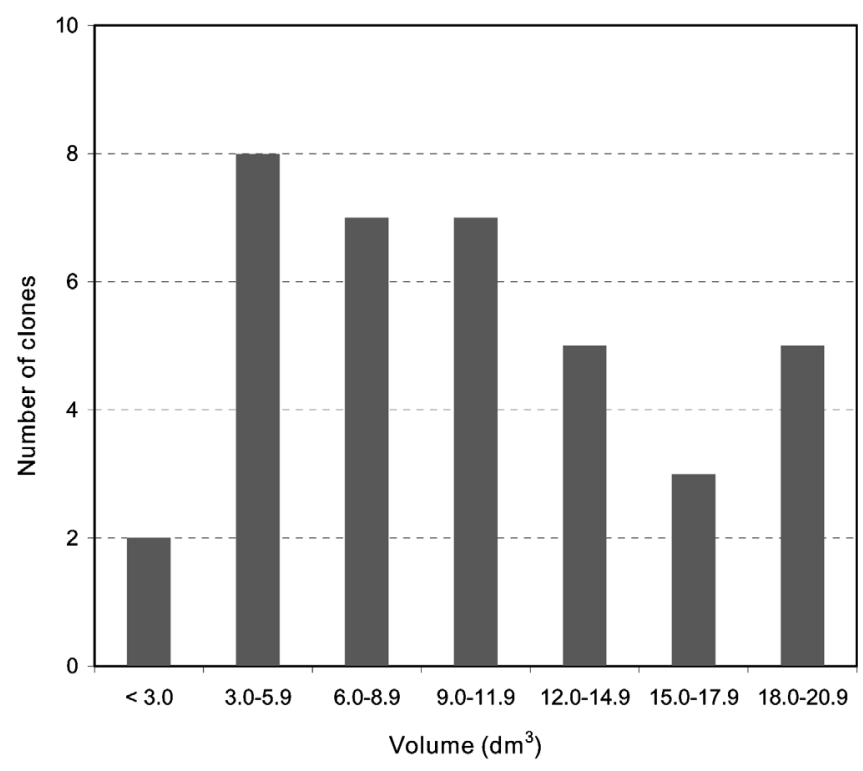

Figure 1. - Frequency distribution of the 37 somatic clones of coastal Douglas-fir for mean stem volume at $7 \frac{1}{2}$-years across tests LV1, TH2, TH3, VA4 and SP5. the two zygotic families (Table 3). The wide distribution of the somatic clones for growth and the associated strong growth performance of a relatively small group of clones suggest a fundamental need for reliable genetic testing of somatics before individual clones are selected for commercial use in plantations. Thorough testing certainly seems important during these early stages of development of SE propagation technology. The wide performance distribution of somatic clones, together with the propagation scale offered by SE technology, certainly provides great opportunities for the deployment of SE clones.

The eight high growth somatic clones came mainly from full-sib families that had themselves been chosen for high growth, including: six clones from the Twin Harbors family AxB, one clone from Twin Harbors AxC and one from FxB. None of the top eight somatic clones for growth were propagated from the Longview family DxE that had previously been selected on high stem quality (although this family had also demonstrated reasonable growth). The dominance of $\mathrm{AxB}$ amongst the top eight somatic clones suggests that the genetic potential of zygotic families for growth is not lost through the somatic propagation process. It is also worth mentioning that an adverse clonal genetic association appears to exist between growth and stem sinuosity of somatic clones of coastal Douglas-fir (discussed later).

(2) Stem Quality: Somatic clones generally had better stem quality (reflected in a lower sinuosity score) than the zygotic full-sib families of coastal Douglas-fir in this study. For example, the mean stem sinuosity of all 37 clones was score 0.34 compared with score 0.47 for the two zygotic families (Table 3). The eight high growth clones had, on average, poorer stem sinuosity (reflecting an adverse clonal genetic association) but some fast growing clones did have quite acceptable stem sinuosity (discussed later). The eight of 37 somatic clones having the best (lowest) mean stem sinuosity score are not listed in Table 3; however, five of these clones were from the Longview family DxE, with two clones from family $\mathrm{AxB}$, and one from AxC. This representation of the good stem quality family DxE from the stem quality nucleus breeding population in the list of best sinuosity somatic clones again suggests that genetic potential of superior zygotic families is not lost through the process of somatic propagation. 
Table 4. - ASREML estimates and standard errors ( \pm se) determined with fitted MoDEL 2 for overall means, variance components and clonal heritabilities for stem height, diameter at breast-height (DBH), stem sinuosity and volume for coastal Douglas-fir somatic clones at $7 \frac{1}{2}$-years across the genetic tests LV1, TH2, TH3, VA4 and SP5.

\begin{tabular}{|c|c|c|c|c|}
\hline & $\begin{array}{l}\text { Height } \\
\text { (m) }\end{array}$ & $\begin{array}{l}\text { DBH } \\
(\mathrm{mm})\end{array}$ & $\begin{array}{l}\text { Volume } \\
\left(\mathrm{dm}^{3}\right)\end{array}$ & $\begin{array}{l}\text { Sinuosity } \\
\text { (scorc) }\end{array}$ \\
\hline \multicolumn{5}{|l|}{ Overall Means: } \\
\hline Mean $(\mu \pm$ se $)$ & $5.4 \pm 0.3$ & $61 \pm 3.0$ & $9.8 \pm 1.1$ & $0.34 \pm 0.07$ \\
\hline \multicolumn{5}{|l|}{ Variance Components: } \\
\hline Families $\left(\sigma_{F}^{2} \pm\right.$ se $)$ & $0.13 \pm 0.24$ & zero & $2.0 \pm 4.3$ & $0.010=0.02$ \\
\hline Family $x$ test interaction $\left(\sigma_{\mathrm{FT}}^{2} \pm \mathrm{se}\right)$ & $0.02 \pm 0.01$ & $1.8 \pm 2.0$ & $0.8 \pm 0.5$ & $0.004 \pm 0.01$ \\
\hline Clones within-families $\left(\sigma_{c}^{2} \pm s c\right)$ & $1.40 \pm 0.35$ & $312 \pm 75$ & $29.6 \pm 7.4$ & $0.059 \pm 0.02$ \\
\hline Clone $\mathrm{x}$ test interaction $\left(\sigma_{C T}^{2} \pm \mathrm{se}\right)$ & $0.08 \pm 0.02$ & $10.7 \pm 3.3$ & $1.5 \pm 0.4$ & $0.009 \pm 0.01$ \\
\hline Within-clone residual $\left(\sigma_{e}^{2} \pm \mathrm{se}\right)$ & $0.69 \pm 0.02$ & $164 \pm 5.6$ & $17.5 \pm 0.6$ & $0.137 \pm 0.01$ \\
\hline Phenotypic variance $\left(\sigma_{\mathrm{P}}^{2}\right)^{\Lambda}$ & $2.31 \pm 0.40$ & $488 \pm 75$ & $51.4 \pm 8.1$ & $0.219 \pm 0.02$ \\
\hline \multicolumn{5}{|c|}{ Pooled Heritabilities (No Units of Measurement): } \\
\hline Clonal heritability $\left(\mathrm{H}_{\mathrm{C}}^{2} \pm \mathrm{se}\right)^{\mathrm{B}}$ & $0.61 \pm 0.09$ & $0.64 \pm 0.06$ & $0.58 \pm 0.08$ & $0.26 \pm 0.06$ \\
\hline
\end{tabular}

\section{Clonal Variances and Heritabilities}

(1) Growth: Table 4 presents variance components and heritabilities for growth and stem sinuosity of the somatic clones to $7 \frac{1}{2}$-years across the five Washington and Oregon tests. The growth traits all exhibited high clonal heritabilities with low standard errors, including: $\mathrm{H}^{2}{ }_{\mathrm{C}}=0.64 \pm 0.06$ for $\mathrm{DBH}, 0.61 \pm 0.09$ for height and $0.58 \pm 0.08$ for volume (Table 4 ). The high heritabilities and low standard errors for growth traits are characterised by very high levels of variation between clones within-families $\left(\sigma_{\mathrm{C}}^{2}\right)$ and relatively low levels of family $\left(\sigma_{\mathrm{F}}^{2}\right)$ and interaction variation $\left(\sigma_{\mathrm{CT}}^{2}\right.$ and $\left.\sigma_{\mathrm{FT}}^{2}\right)$. For example, the magnitude of $\sigma_{C}^{2}$ for volume growth to $7 \frac{1}{2}$-years was almost 15 times higher than the magnitude of $\sigma_{\mathrm{F}}^{2}$ (Table 4); although it is important to emphasize that $\sigma_{\mathrm{F}}^{2}$ is an estimate from among only four families in the current study. DEAN (2008) presents the only other published estimates of clonal genetic parameters for growth of coastal Douglas-fir in field tests. The estimates of DEAN (2008) are lower than the present study with $\mathrm{H}^{2}{ }_{\mathrm{C}}=0.20$ to 0.25 for height, $\mathrm{DBH}$ and volume growth to $5 \frac{1}{2}$-years across Washington and Oregon.
It is interesting to compare the parameter estimates reported here for somatic clones with published genetic parameter estimates for zygotic trees of coastal Douglasfir. DEAN and STONECYPHER (2006) estimated individual heritabilities of $0.18-0.22$ for height of coastal Douglasfir between four and 17 years after planting polymix families across three field tests in Oregon. These field tests of DEAN and STONECYPHER (2006) had similar silviculture to the somatic tests reported here. CAMPBELL et al. (1986), KING et al. (1988), NAMKOONG et al. (1972), ADAMs and JoYCE (1990) and JoHNSON et al. (1997) also present estimates of genetic parameters for field growth of zygotic coastal Douglas-fir progeny tests. The individual heritability estimates of CAMPBELL et al. (1986) and KING et al. (1988) ranged between 0.12-0.21 for height growth of zygotic coastal Douglas-fir at five to 13 years after planting.

The estimates of $\mathrm{H}^{2}{ }_{\mathrm{C}}$ presented in Table 4 reflect the ratio of the variance between-clones within full-sib families $\left(\sigma_{\mathrm{C}}^{2}\right)$ divided by the phenotypic variance $\left(\sigma_{\mathrm{p}}^{2}\right.$; Equations 3 and 4). These clonal heritabilities give an indication of the degree to which a somatic clone's superiority

Table 5. - ASREML estimates with fitted MODEL 3 of clonal heritabilities and standard errors for stem height, diameter at breast-height (DBH), volume and stem sinuosity for coastal Douglas-fir somatic clones at $7 \frac{1}{2}$-years in each of the genetic tests LV1, TH2, TH3, VA4 and SP5. Overall between-test clonal correlations are also shown.

\begin{tabular}{lcccc}
\hline Genetic Test & Height & DBH & Volume & Sinuosity \\
\hline \hline & & & & \\
LV1 (Longview, Washington) & $0.68 \pm 0.06$ & $0.67 \pm 0.06$ & $0.62 \pm 0.06$ & $0.39 \pm 0.07$ \\
TH2 (Twin Harbors, Washington) & $0.73 \pm 0.05$ & $0.66 \pm 0.06$ & $0.65 \pm 0.06$ & $0.31 \pm 0.07$ \\
TH3 (Twin Harbors, Washington) & $0.71 \pm 0.05$ & $0.69 \pm 0.06$ & $0.69 \pm 0.06$ & $0.42 \pm 0.07$ \\
VA4 (Vail, Washington) & $0.67 \pm 0.06$ & $0.65 \pm 0.06$ & $0.65 \pm 0.06$ & $0.16 \pm 0.05$ \\
SP5 (Springfield, Oregon) & $0.67 \pm 0.06$ & $0.63 \pm 0.06$ & $0.63 \pm 0.06$ & $0.36 \pm 0.07$ \\
Between-test clonal correlation & $0.96 \pm 0.01$ & $0.97 \pm 0.01$ & $0.98 \pm 0.01$ & $0.98 \pm 0.01$ \\
\hline
\end{tabular}


across tests is repeatable, relative to other clones from the same family. As already mentioned, any c-effects that may be present in this study are completely confounded with $\sigma^{2}$, and these effects may lead to substantial bias in the genetic parameter estimates. IsIK et al. (2003) and BALTUNIS et al. (2005) comment on the influence c-effects can have on genetic parameter estimates in conifers. In analyses not reported here, clonal heritability was also determined using a $\sigma^{2}{ }_{\mathrm{C}}$ component estimated as variance between-clones ignoring families (i.e. with FAMILY $_{k}$ and FAMILY.TEST ${ }_{\text {ik }}$ omitted from the MODEL 2 ). These estimates of $\mathrm{H}^{2}$ ignoring family were almost identical to those presented in Table 4; reflecting the low level of $\sigma_{\mathrm{F}}^{2}$ observed in this study.

Table 5 presents ASREML estimates with fitted MoDEL 3 of clonal heritabilities and standard errors of growth of the somatic clones to $7 \frac{1}{2}$-years in each individual genetic test. While the magnitude of the heritabilities is almost always higher in the individual tests, compared with estimates in Table 4 (due to clone $\mathrm{x}$ test effects), the $\mathrm{H}^{2}{ }_{\mathrm{C}}$ for each trait are remarkably consistent across tests (Table 5).

(2) Stem Quality: The stem sinuosity score of coastal Douglas-fir had a $\mathrm{H}^{2}{ }_{\mathrm{C}}$ of $0.26 \pm 0.06$ to $7 \frac{1}{2}$-years across the five Washington and Oregon genetic tests (Table 4). As with growth traits, the clonal heritability estimate of stem sinuosity is confounded with any c-effects that are present.

\section{Clonal Stability}

Stability of clonal performance across tests was very high for all growth traits and stem sinuosity, with between-test correlations of 0.96 to $0.98 \pm 0.01$ (Table 5). These between-test correlations of near unity imply that clones rank quite consistently across each of the five tests in Oregon and Washington. A correlation of zero would imply there is no correspondence at all between rankings across the tests. DEAN (2008) also reported stable clonal performance for growth of somatic trees across similar site environments in Washington and Oregon, although the absolute magnitude of the between-test correlations of DEAN (2008) was somewhat lower with $0.84 \pm 0.04$ for height, $\mathrm{DBH}$ and volume at $5 \frac{1}{2}$-years.

The stability of genetic expression that is evident from the high between-test clonal correlations is reflected in the low levels of variance due to clone $\mathrm{x}$ test interactions. Indeed, the variance between-clones within families $\left(\sigma_{C}^{2}\right)$ is almost 20 times greater than variance due to clone $\mathrm{x}$ test interaction $\left(\sigma_{\mathrm{CT}}^{2}\right)$ for volume growth of the somatic clones to $7 \frac{1}{2}$-years across the tests (Table 4). While this apparent stability of clones is certainly encouraging for the future of SE in clonal forestry of coastal Douglas-fir it should be remembered that these results are based on tests of only 37 somatic clones.

\section{Correlations among Traits}

Within families, height, $\mathrm{DBH}$ and volume were all closely genetically correlated at the clonal level (correlations of 0.97 to $0.98 \pm 0.01$; Table 6 ). Stem sinuosity score had quite strong positive (unfavourable) clonal cor-
Table 6. - ASREML estimates with fitted Model 4 of clonal and phenotypic correlations ( \pm standard errors) among stem height, diameter at breast-height (DBH), volume and stem sinuosity of coastal Douglas-fir somatic clones at $7 \frac{1}{2}$-years across tests LV1, TH2, TH3, VA4 and SP5.

\begin{tabular}{lccc}
\hline & DBH & Volume & Sinuosity \\
\hline \hline Genetic Correlations: & & & \\
Height & $0.98 \pm 0.01$ & $0.97 \pm 0.01$ & $0.67 \pm 0.10$ \\
DBH & & $0.98 \pm 0.01$ & $0.63 \pm 0.11$ \\
Volume & & & $0.68 \pm 0.10$ \\
Phenotypic Correlations: & & & \\
Height & $0.95 \pm 0.01$ & $0.91 \pm 0.01$ & $0.40 \pm 0.06$ \\
DBH & & $0.95 \pm 0.01$ & $0.40 \pm 0.06$ \\
Volumc & & & $0.40 \pm 0.06$ \\
\hline
\end{tabular}

relations with height $(0.67 \pm 0.10), \mathrm{DBH}(0.63 \pm 0.11)$ and volume $(0.68 \pm 0.10 ;$ Table 6$)$. These correlations indicate that clonal selection within families for growth can be accompanied by deterioration in sinuosity unless selection pressure is also applied to the stem quality trait.

The adverse clonal association between growth and stem sinuosity was also apparent in the higher overall stem sinuosity of the top eight somatic clones selected on volume growth (Table 3). However, three of these top eight growth clones (including the fastest growing clone) actually had quite favourable mean stem sinuosity scores; these are the so-called "correlation breakers" and likely candidates for deployment. Three of the top eight clones had very poor sinuosity and would not normally be included in commercial forestry programs.

\section{Conclusions}

Following are the main conclusions from analyses of five genetic tests of 37 somatic clones developed from four full-sib coastal Douglas-fir families; and measured at $7 \frac{1}{2}$-years -

(1) Performance of Somatic Clones: On average somatic trees grew more slowly and had better stem sinuosity than the zygotic trees of coastal Douglas-fir across the five genetic tests in Washington and Oregon. However, mean clonal performance for growth was widely distributed and the top eight (or 20\%) somatic clones for growth had an overall mean volume $25 \%$ greater than the mean of the zygotic families. This study provides evidence that the genetic potential of zygotic families for growth and stem sinuosity is not lost through somatic propagation.

(2) Genetic Parameters: Growth traits exhibited high clonal heritabilities ranging from $\mathrm{H}^{2}{ }_{\mathrm{C}}=0.58$ to 0.64 with low standard errors. Stem sinuosity score had a lower $\mathrm{H}^{2}{ }_{\mathrm{C}}$ of $0.26 \pm 0.06$. The growth traits were all closely correlated at the clonal level, but adversely correlated with stem sinuosity. These clonal parameters are confounded with any c-effects due to propagation.

(3) Clonal Stability: Clonal performance for growth was very stable across tests with between-test correlations of 0.96 to $0.98 \pm 0.01$ for growth and sinuosity in 
the current study. The stability of genetic expression that is evident from the high between-test clonal correlations is reflected in low levels of variance due to clone $\mathrm{x}$ test interactions.

\section{Acknowledgements}

The following people made significant contributions to Weyerhaeuser's Advanced-Generation Douglas-fir Genetics Program during the propagation, establishment and measurement of the tests reported here: JAMES BENSON, Pramod Gupta, Lyle Linton, Mark Heffner and H. JAMES RENO.

\section{References}

Adams, W. T. and D. G. JoycE (1990): Comparison of selection methods for improving volume growth in young coastal Douglas-fir. Silvae Genet. 39: 219-226.

Baltunis, B. S., D. A. Huber, T. L. White, B. Goldfarb and H. E. STELzer (2005): Genetic effects of rooting loblolly pine stem cuttings from a partial diallel mating design. Can. J. For. Res. 35: 1098-1108.

Benowicz, A., S. C. Grossnickle and Y. A. El-Kassaby (2002): Field assessment of Douglas-fir somatic and zygotic seedlings with respect to gas exchange, water relations, and frost hardiness. Can. J. For. Res. 32 1822-1828.

Bruce, D. and D. J. Demars (1974): Volume equations for second-growth Douglas-fir. Forest Service Research Note PNW-239, USDA, PNWFRES: Portland, Oregon.

Campbell, R. K., R. M. Echols and R. W. StonecypheR (1986): Genetic variances and interactions in 9-year Douglas-fir grown at narrow spacings. Silvae Genet. 35: 24-32.

Cheliak, W. M. and D. L. Rogers (1990): Integrating biotechnology into tree improvement programs. Can. J. For. Res. 20: 452-463.

Dean, C. A. (2007): Weyerhaeuser's Douglas-fir Tree Improvement Program - Beyond 50 years. In: Joint SFTIC/WFGA Conference: Tree Improvement in North America: Past, Present and Future. June 19-22, 2007. Texas: USA (http://tfsweb.tamu.edu/conferences/ treeconference/).

DEAN, C. A. (2008): Genetic parameters of somatic clones of coastal Douglas-fir at $5 \frac{1}{2}$-years across Washington and Oregon, USA. Silvae Genet. 57: 269-275.

Dean, C. A. and R. W. Stonecypher (2006): Early selection of Douglas-fir across south central coastal Oregon, USA. Silvae Genet. 55: 135-141.

Dunstan, D. I. (1988): Prospects and progress in conifer biotechnology. Can. J. For. Res. 18: 1497-1506.

Gilmour, A. R., B. J. Gogel, B. R. Cullis and R. ThompSON (2006): ASREML User Guide Release 2.0 VSN International Ltd, Hemel Hempstead, HP1 1ES, UK.

Grossnickle, S. C., D. Cyr and D. R. Polonenko (1996): Somatic embryogenesis tissue culture for the propagation of conifer seedlings: A technology comes of age. Tree Planters' Notes 47: 48-57.
Grossnickle, S. C. and J. E. MAJOR (1994): Interior spruce seedlings compared with emblings produced from somatic embryogenesis. II. Stock quality assessment prior to field planting. Can. J. For. Res. 24: 1385-1396.

Grossnickle, S. C., J. E. MAJor and R. S. FolK (1994): Interior spruce seedlings compared with emblings produced from somatic embryogenesis. I. Nursery development, fall acclimation and over-winter storage. Can. J. For. Res. 24: 1376-1384.

Gupta, P. K., R. Timmis, K. Timmis, W. Carlson, J. Grob and E. WELTY (1994): Plantlet regeneration via somatic embryogenesis in Douglas-fir (Pseudotsuga menziesii). In TAPPI Proc. Bio. Science Symposium Pp. 35-39. Norcross, GA.

IsIK, F., Li BAILIAN and J. FrAmpton (2003): Estimates of additive, dominance and epistatic genetic variances from a clonally replicated rest of loblolly pine. Forest Science 49: 77-88.

Johnson, G. R., R. A. Sniezko and N. L. MANDEL (1997): Age trends in Douglas-fir genetic parameters and implications for optimum selection age. Silvae Genet. 46: 349-358.

King, J. N., F. C. YeH and J. C. H. Heaman (1988): Selection of growth and yield traits in controlled crosses of coastal Douglas-fir. Silvae Genet. 37: 158-164.

Nagmani, R., M. A. Johnson and R. J. Dinus (1991): Effect of explant and media on initiation, maintenance, and maturation of somatic embryos in Pseudotsuga menziesii var. menziesii (MIrB.) Franco (Douglas-fir). In: Woody Plant Biotechnology. Pp. 171-178. (Edit. M. R. Ahuja). Plenum Press, New York.

Namkoong, G., R. A. Usanis and R. R. Silen (1972): Agerelated variation in genetic control of height growth in Douglas-fir. Theor. and Appl. Genet. 42: 151-159.

O’Neill, G. A., J. H. Russell, B. D. Hooge, P. K. Ott and C. B. D. Hawkins (2005): Estimating gains from genetic tests of somatic emblings of interior spruce. For. Genet. 12: $57-66$.

Patterson, H. D. and R. Thompson (1971): Recovery of interblock information when block sizes are unequal. Biometrika 58: 545-54.

Roberts, D. R., F. B. Webster, D. R. Cyr, T. K. Edmonds, S. M. A. Grimes and B. C. S. Sutton (1995): A delivery system for naked somatic embryos of interior spruce. In: Automation and Environmental Control in Plant Tissue Culture. Pp. 245-256. (Edit. J. Aitken-Christie, T. KozAI and M. A. L. SMith). Kluwer Academic Publishers, Dordrecht, The Netherlands.

Searle, S. R., G. Casella and C. E. McCulloch (1992): Variance Components. John Wiley and Sons: New York.

Stonecypher, R. W., R. F. Piesch, G. G. Helland, J. G. Chapman and H. J. Reno (1996): Results from genetic tests of selected parents of Douglas-fir (Pseudotsuga menziesii [MIRB.] FrANCO) in an applied tree improvement program. For. Sci. Monograph 32: 1-35.

SutTon, B. (2002): Commercial delivery of genetic improvement to conifer plantations using somatic embryogenesis. Ann. For. Sci. 59: 657-661.

Tautorus, T. E., L. C. Fowke and D. I. Dunstan (1991): Somatic embryogenesis in conifers. Can. J. Bot. 69: 1873-1899. 